\title{
LIGHT INTERCEPTION AND PRODUCTIVITY OF MAIZE INTERCROPPED WITH LEGUMES IN KHARIF SEASON
}

\author{
Q. Naher and M.A. Hossain \\ On- Farm Research Division, BARI,Gazipur 1701, Bangladesh \\ Corresponding E-mail: ofrdjoy@yahoo.com
}

(Received: 09 December 2021, Accepted: 19 December 2021)

Keywords:Light interception, maize legume intercropping, weed growth, productivity

\begin{abstract}
The experiment was carried out at the Bangladesh Agricultural Research institute, Joydebpur, Gazipur during 2012 to evaluate the intercepted PAR in maize intercropped withlegumein comparison to monoculture for better weed suppression, productivity and economic benefits in kharif season. There were 17 treatments in the experiment viz., $\mathrm{T}_{1}=$ Sole maize (no weeding), $T_{2}=$ Maize + Mungbean (no weeding), $T_{3}=$ Maize + Mungbean (weeding at $20 \mathrm{DAE}$ ), $\mathrm{T}_{4}=$ Maize + Mungbean (weeding at $\left.40 \mathrm{DAE}\right), \mathrm{T}_{5}=$ Maize + Mungbean (weeding at 20 and $40 \mathrm{DAE}$ ), $\mathrm{T}_{6}=$ Maize + Soybean (no weeding), $\mathrm{T}_{7}=$ Maize + Soybean (weeding at $20 \mathrm{DAE}), \mathrm{T}_{8}=$ Maize + Soybean (weeding at $\left.40 \mathrm{DAE}\right), \mathrm{T}_{9}=$ Maize + Soybean (weeding at 20 and $40 \mathrm{DAE}$ ), $\mathrm{T}_{10}=$ Maize + Blackgram (no weeding), $\mathrm{T}_{11}=$ Maize + Blackgram ( weeding at $20 \mathrm{DAE}), \mathrm{T}_{12}=$ Maize + Blackgram ( weeding at 40 $\mathrm{DAE}$ ), $\mathrm{T}_{13}=$ Maize + Blackgram (weeding at 20 and $\left.40 \mathrm{DAE}\right) \mathrm{T}_{14}=$ Sole maize (weed free), $\mathrm{T}_{15}=$ Sole Mungbean (weed free), $\mathrm{T}_{16}=$ Sole Soybean (weed free) and $\mathrm{T}_{17}=$ Sole Blackgram (weed free).The results showed that PAR was significantly affected by cropping system, where it was higher in intercropping systems compared to sole crop . Regarding weed control, intercrops were more effective than sole crops and it was related to lower availability of PAR for weeds in intercropping systems. The highest grain yield $\left(8.05 \mathrm{t} \mathrm{ha}^{-1}\right)$. was obtained from weed free sole maize Among all intercropping, maize + mungbean along with two hand weeding gave the highest yield (maize: $7.18 \mathrm{t} \mathrm{ha}^{-1}$; 572.6 $\mathrm{kg} \mathrm{ha}^{-1}$ mungbean), maize equivalent yield $(\mathrm{MEY})=12.49 \mathrm{t} \mathrm{ha}^{-1}$ and $\left.\mathrm{BCR}=2.84\right)$. From the study it can be concluded that maize mungbean intercropping with two hand weedings at 20 and 40 DAE would be the best in reducing weed growth, producing maximum yield and net return in intercropping systems under kharif season.
\end{abstract}

\section{Introduction}

Maize (Zeamays L.) is the third most important cereal next to rice and wheat, in the world as well in Bangladesh. Many factors are responsible for the low yields of maize in Bangladesh.The average yield of maize in Bangladesh is $3.0 \mathrm{t} / \mathrm{ha}$ (BBS, 2017) which is too low compared tomanyother countries. Weedis one of the major constraints of maize production in our country. They cause yield losses worldwide with an average of 12.8 per cent despite weed control practices and $29.2 \%$ in case of unchecked weed growth (Dogan et al., 2004). Although maize plant is vigorous and tall in nature, yet it is very sensitive to weed competition at early stages of growth. Hence, it is necessary that maize should be kept free of weeds for the first 30 days after crop emergence. Now-a-days, the labour force is diminishing in agriculture. Management of weeds in cropped field has become a real challenge to the farmers. The production and productivity of maize is reduced due to competition offered by weeds for growth resources viz., nutrients, moisture, sunlight and space during entire vegetative growth and early reproductive stage.

Intercropping is an agricultural practice which can be used for decreasing the dependency on chemical herbicides in weed control (Banik et al., 2006).Intercropping generates beneficial biological inter- 
actions between crops increasing grain yield and stability, more efficient using available resources and reducing weed pressure (Kadziuliene et al., 2009). Many authors indicated the limiting effect of intercropping on the number and biomass of weeds (Gharineh and Moosavi, 2010). Weed suppression in intercropping through more efficient use of environmental resources by component crops has been reported (Poggio, 2005). Light interception and light use efficiency (LUE) of crops directly determine dry matter accumulation and yield formation, depending on canopy traits such as the distribution and photosynthetic capacity of the leaves (Gao et al., 2010). Higher light interception or a higher LUE can result in greater productivity. Numerous studies reported that yield advantage in intercropping was mainly due to greater light interception and use efficiency. Katsaruware and Manyanhaire (2009) reported that maize-cowpea intercrops reduced weed biomass when compared to sole crops and it was as a result of limited availability of resources to weed species, where incoming PAR reaching the ground was reduced by maize-cowpea intercrop. Baumann et al. (2000) reported that intercropping increase light interception by the weakly competitive component and can, therefore, shorten the critical period for weed control and reduce growth and fecundity of late-emerging weeds. The tall maize $\mathrm{C}_{4}$ plants canopy provides greater light penetration so that better light distribution is available over the leaves located in lower state. The under storey short stature $\mathrm{C}_{3}$ legume crop is shaded but this is partially offset by its higher photosynthetic rates per unit radiant energy at a low light intensity and it may be compatible crop as intercrop with maize (Muoneke et al., 2007). Among the intercrops, blackgram, greengram, soybean and cowpea were generally found to increase the yield of maize or gave similar yield along with an additional yield of intercrop ( $\mathrm{Li}$ et al., 2001). The aim of the present study was to quantify the effect of intercropping on weed suppression by evaluating the amount of photosynthetically active radiation (PAR) consumption.

\section{Materials and Methods}

The experiment was conducted at the On-farm research field of Bangladesh Agricultural Research Institute, Joydebpur, Gazipurduring kharif season of 2012. The experiment site was located at Chhiata Series under Agro-Ecological Zone-28. Before opening the land, the soil samples were taken and showed that the soil of the experimental field was loam in texture and low in organic matter $(1.16 \%)$. The soil $\mathrm{pH}$ is 7.2 and contained very low amount of total nitrogen $(0.061 \%)$, phosphorus $(3 \mu \mathrm{g} / \mathrm{g})$, sulphur $(0.6 \mu \mathrm{g} / \mathrm{g})$, zinc $(3.54 \mu \mathrm{g} / \mathrm{g})$, boron $(0.44 \mu \mathrm{g} / \mathrm{g})$ and potassium $(0.13 \mathrm{meq} . / 100 \mathrm{~g}$ soil $)$.During the crop growth period average monthly maximum temperature was recorded in the month of April $\left(22.5^{\circ}\right.$ C). There were 17 treatments in the study viz., $\mathrm{T}_{1}=$ Sole maize (no weeding), $\mathrm{T}_{2}=$ Maize + Mungbean (no weeding), $\mathrm{T}_{3}=$ Maize + Mungbean (weeding at $20 \mathrm{DAE}$ ), $\mathrm{T}_{4}=$ Maize + Mungbean (weeding at 40 $\mathrm{DAE}$ ), $\mathrm{T}_{5}=$ Maize + Mungbean (weeding at 20 and $40 \mathrm{DAE}$ ), $\mathrm{T}_{6}=$ Maize + Soybean (no weeding), $\mathrm{T}_{7}=$ Maize + Soybean (weeding at $20 \mathrm{DAE}), \mathrm{T}_{8}=$ Maize + Soybean (weeding at $40 \mathrm{DAE}$ ), $\mathrm{T}_{9}=$ Maize + Soybean (weeding at 20 and $40 \mathrm{DAE}$ ), $\mathrm{T}_{10}=$ Maize + Blackgram (no weeding), $\mathrm{T}_{11}=$ Maize + Blackgram ( weeding at $20 \mathrm{DAE}$ ), $\mathrm{T}_{12}=$ Maize + Blackgram (weeding at $\left.40 \mathrm{DAE}\right), \mathrm{T}_{13}=$ Maize + Blackgram (weeding at 20 and $40 \mathrm{DAE}$ ) $\mathrm{T}_{14}=$ Sole maize (weed free), $\mathrm{T}_{15}=$ Sole Mungbean (weed free), $\mathrm{T}_{16}=$ Sole Soybean (weed free) and $\mathrm{T}_{17}=$ Sole Blackgram (weed free)were studied. Maize was sown in $75 \mathrm{~cm} \times 20 \mathrm{~cm}$ spacing both in sole and intercrop system. Planting arrangement in intercrop treatments, two rows of legumes accommodated between one row of maize.The trialwaslaid out in a randomized complete block design with three replications. The plot size was $5.0 \mathrm{~m} \times 4.5 \mathrm{~m}$. Maize var. BARI Hybrid Maize-7, mungbean var. BARI Mung-5, blackgramvar. BARI Mash-3 and soybean var. BARI Soybean-5 were used as test crops. Fertilizer was applied for maize at the rate of 250-50-100-44-5-2 kg of N, P, K,S, Znand $\mathrm{Bha}^{-1}$, respectively, from urea, triple super phosphate, muriate of potash, gypsum, zinc sulphate and boric acid, respectively. Half amount of $\mathrm{N}$ and full dose of other fertilizers were incorporated into the soil at the time of final land preparation. The remaining urea was top dressed in two equal installments as top dressing at 8-10 leaf stage (30-35 DAS) and at tasseling stage (55DAS) followed by irrigation. Fertilizers were applied for sole mungbean, blackgram and soybean at the rate of 21-17-18 and 23-18-18 $\mathrm{kg}$ of $\mathrm{N}, \mathrm{P}, \mathrm{K} \mathrm{ha}^{-1}$, respectively from Urea, TSP, MoP, respectively. Half 
amount of urea and full amount of other fertilizers were applied at the time of final land preparation. Additional fertilizers were not applied for legumes in intercrop situation. Urea was top dressed as band placement in maize rows only. Sowing of both maize and legumes were done on 15March 2012. Weed management was done as per treatment specification. Mature mungbean and blackgram were harvested at 65 DAE while soybean was harvested at 100 DAE. Maize was harvested at 120DAS. Legume equivalent yield and maize equivalent yield were computed using the formula of Bandyopadhaya (1984).

Maize equivalent yield $=\mathrm{Yim}+(\mathrm{Yil} \times \mathrm{Pl}) / \mathrm{Pm}$

Where,

$$
\begin{aligned}
& \text { Yil }=\text { Yield of intercrop legume }\left(\mathrm{t} \mathrm{ha}^{-1}\right) \\
& \text { Yim }=\text { Yield of intercrop maize }\left(\mathrm{t} \mathrm{ha}^{-1}\right) \\
& \mathrm{Pm}=\text { Selling price of maize } \\
& \mathrm{Pl}=\text { Selling price of legume }
\end{aligned}
$$

Weed control efficiency (WCE) was calculated using the following formula (Curz et al., 1986).

$\mathrm{WCE}=\frac{\mathrm{DWC}-\mathrm{DWT}}{\mathrm{DWC}} \times 100$

DWC $=$ Dry weight of weeds in the weedy check

DWT $=$ Dry weight of weeds in the weeding treatment

The portion of intercepted PAR (PARint) was calculated using the following equation and expressed in percentage (Ahmed et al., 2010).

PARint $(\%)=\frac{\text { PARinc- PARt }}{\text { PARinc }} \times 100$

Where, PARint $=$ Intercepted PAR, PARinc $=$ incident PAR and PARt $=$ transmitted PAR

The collected data were statistically analyzed by using MSTAT programme and the means were adjudged by using LSD. Economic analysis was also done.

\section{Results and Discussion}

Weed density, weed dry weightand weed control efficiency (WCE) asaffected by different intercropping systems and weeding regime are presented in Table 1. Intercropping systems significantly reduced the weed population and weed dry biomass than sole cropping of maize under unweeded situation. Cynodondactylon, Eleusineindica, Echinochloa crus-galli, Paspalumconjugatum, Cyperusrotundus L. and Physalisheterophyll were the common and dominant weeds in the maize field. Maximum weed density $\left(363.3 \mathrm{~m}^{-2}\right.$ at $20 \mathrm{DAE}$ and $426 \mathrm{~m}^{-2}$ at $\left.40 \mathrm{DAE}\right)$ and weed dry weight $(216.8 \mathrm{~g}$ at $20 \mathrm{DAE}$ and $284.4 \mathrm{~g}$ at $40 \mathrm{DAE}$ ) were recorded in unweeded monoculture maize crop. Among the three different intercropping systems, $\mathrm{T}_{5}$ (Maize + Mungbean with two hand weeding sat 20 and 40 DAE) treatment provided the lowest weed density $\left(275.3 \mathrm{~m}^{-2}\right.$ at $20 \mathrm{DAE}$ and $53.33 \mathrm{~m}^{-2}$ at $\left.40 \mathrm{DAE}\right)$ and weed dry weight (184.3 g at $20 \mathrm{DAE}$ and $14.07 \mathrm{~g}$ at $40 \mathrm{DAE})$ and it was followed by maize + soybean and maize + blackgram systems. The reduction in weed population and weed dry biomass in intercropping systems mightbe attributed to shading effect and competition stress created by canopy of more number of crop plants in a unit area having suppressing effect on associated weeds thus preventing the weeds to attain full growth. Similar results were reported by Dwivedi and Shrivastava (2011).At 20 DAE, the weed control efficiency (WCE) in all the treatments was almost same while at 40 DAE the WCE varied significantly in all treatments. Weed control efficiency of different treatments varied from 14.8-25.3\% at $20 \mathrm{DAE}$ and $17.9-87.53 \%$ at $40 \mathrm{DAE}$. Among the weed control treatments, two hand weeding sat 20 and 40 DAE in maize + mungbean caused the highest weed control efficiency (24.0-87.5\%) while it 
was (19.55-85.46\%) in maize + soybean and (19.82-80.09\%) in maize + blackgram treatments. Pandey and Prakash (2002) reported that maize and legume intercropped either as paired rows + two rows of legume or one row of legume in between two rows of maize adversely affected the weed growth and caused 22.4 and $31.9 \%$ weed growth suppression as compared with sole maize, respectively. Among the intercropping systems, Maize + Soybean unweeded plot gave lower WCE (18.83-22.34\%).

Table 1. Weed density, weed dry weight and weed control efficiency in different maize +legumes intercropping systems during the Kharif season of 2012

\begin{tabular}{lcccccc}
\hline Treatments & \multicolumn{2}{c}{$\begin{array}{c}\text { Weed density } \\
\left(\mathbf{n o .} \mathbf{~ m}^{-2}\right)\end{array}$} & \multicolumn{2}{c}{$\begin{array}{c}\text { Weed dry weight } \\
\left(\mathbf{g ~ m}^{-2}\right)\end{array}$} & \multicolumn{2}{c}{$\begin{array}{c}\text { Weed control efficiency } \\
(\%)\end{array}$} \\
\cline { 2 - 7 } & $\mathbf{2 0 ~ D A E}$ & $\mathbf{4 0} \mathbf{D A E}$ & $\mathbf{2 0 ~ D A E}$ & $\mathbf{4 0 ~ D A E}$ & $\mathbf{2 0 ~ D A E}$ & $\mathbf{4 0 ~ D A E}$ \\
\hline $\mathrm{T}_{1}$ & $363.3 \mathrm{a}$ & $426.0 \mathrm{a}$ & $216.8 \mathrm{a}$ & $284.4 \mathrm{a}$ & - & - \\
$\mathrm{T}_{2}$ & $284.7 \mathrm{~cd}$ & $324.3 \mathrm{c}$ & $190.5 \mathrm{cde}$ & $178.0 \mathrm{~b}$ & $21.32 \mathrm{abc}$ & $23.84 \mathrm{e}$ \\
$\mathrm{T}_{3}$ & $283.0 \mathrm{~cd}$ & $113.0 \mathrm{~d}$ & $189.1 \mathrm{cde}$ & $25.61 \mathrm{e}$ & $21.82 \mathrm{abc}$ & $73.40 \mathrm{~d}$ \\
$\mathrm{~T}_{4}$ & $270.7 \mathrm{~d}$ & $326.3 \mathrm{c}$ & $181.2 \mathrm{e}$ & $157.9 \mathrm{c}$ & $25.25 \mathrm{a}$ & $23.27 \mathrm{e}$ \\
$\mathrm{T}_{5}$ & $275.3 \mathrm{~cd}$ & $53.33 \mathrm{~g}$ & $184.3 \mathrm{de}$ & $14.07 \mathrm{f}$ & $24.05 \mathrm{ab}$ & $87.53 \mathrm{a}$ \\
$\mathrm{T}_{6}$ & $293.3 \mathrm{bc}$ & $330.7 \mathrm{bc}$ & $196.3 \mathrm{bc}$ & $182.6 \mathrm{~b}$ & $18.83 \mathrm{~cd}$ & $22.34 \mathrm{e}$ \\
$\mathrm{T}_{7}$ & $286.0 \mathrm{~cd}$ & $85.67 \mathrm{ef}$ & $192.2 \mathrm{cde}$ & $35.17 \mathrm{~d}$ & $21.12 \mathrm{abc}$ & $79.82 \mathrm{bc}$ \\
$\mathrm{T}_{8}$ & $289.3 \mathrm{~cd}$ & $333.3 \mathrm{bc}$ & $193.7 \mathrm{~cd}$ & $163.9 \mathrm{c}$ & $20.13 \mathrm{bc}$ & $21.65 \mathrm{e}$ \\
$\mathrm{T}_{9}$ & $291.0 \mathrm{bcd}$ & $62.00 \mathrm{~g}$ & $194.8 \mathrm{~cd}$ & $17.50 \mathrm{ef}$ & $19.55 \mathrm{bc}$ & $85.46 \mathrm{ab}$ \\
$\mathrm{T}_{10}$ & $310.0 \mathrm{~b}$ & $330.3 \mathrm{bc}$ & $207.5 \mathrm{ab}$ & $181.2 \mathrm{~b}$ & $14.13 \mathrm{~d}$ & $22.38 \mathrm{e}$ \\
$\mathrm{T}_{11}$ & $280.7 \mathrm{~cd}$ & $64.00 \mathrm{fg}$ & $187.8 \mathrm{cde}$ & $17.67 \mathrm{ef}$ & $22.42 \mathrm{abc}$ & $84.96 \mathrm{ab}$ \\
$\mathrm{T}_{12}$ & $277.3 \mathrm{~cd}$ & $349.3 \mathrm{~b}$ & $185.6 \mathrm{cde}$ & $179.6 \mathrm{~b}$ & $23.46 \mathrm{abc}$ & $17.87 \mathrm{e}$ \\
$\mathrm{T}_{13}$ & $290.3 \mathrm{bcd}$ & $99.33 \mathrm{de}$ & $190.3 \mathrm{cde}$ & $38.50 \mathrm{~d}$ & $19.82 \mathrm{bc}$ & $76.71 \mathrm{~cd}$ \\
\hline $\mathrm{CV}(\%)$ & 4.48 & 6.49 & 8.32 & 3.10 & 13.99 & 6.91 \\
\hline
\end{tabular}

$\mathrm{T}_{1}=$ Sole maize (no weeding), $\mathrm{T}_{2}=$ Maize + Mungbean (no weeding), $\mathrm{T}_{3}=$ Maize + Mungbean (weeding at $20 \mathrm{DAE}$ ), $\mathrm{T}_{4}=$ Maize + Mungbean (weeding at $40 \mathrm{DAE}), \mathrm{T}_{5}=$ Maize + Mungbean (weeding at 20 and $\left.40 \mathrm{DAE}\right), \mathrm{T}_{6}=\mathrm{Maize}+\mathrm{Soybean}$ (no weeding), $\mathrm{T}_{7}=$ Maize + Soybean (weeding at $\left.20 \mathrm{DAE}\right), \mathrm{T}_{8}=$ Maize + Soybean (weeding at $\left.40 \mathrm{DAE}\right), \mathrm{T}_{9}=\mathrm{Maize}+$ Soybean (weeding at 20 and $40 \mathrm{DAE}$ ), $\mathrm{T}_{10}=$ Maize + Blackgram (no weeding), $\mathrm{T}_{11}=$ Maize + Blackgram ( weeding at 20 $\mathrm{DAE}$ ), $\mathrm{T}_{12}=$ Maize + Blackgram (weeding at $40 \mathrm{DAE}$ ), $\mathrm{T}_{13}=$ Maize + Blackgram (weeding at 20 and $\left.40 \mathrm{DAE}\right)$

\section{Photosynthetically active radiation (PAR) interception}

Light/ solar radiation is the energy that drives crop productivity by the process of photosynthesis (Keating and Cerberry, 1993). It is an important resource essential for crop production. The plants use this resource to produce biomass and part of biomass is converted to economic yield (Trenbath, 1986). Percent radiation interceptions in different intercropping systems with varying weeding regimes in Kharif season are presented in Fig. 1. Among the intercropping systems, maize + mungbean intercropping intercepted more light than maize + soybean and maize + blackgram systems at all growth stages. Maize + mungbean with two hand weeding at 20 and $40 \mathrm{DAE}$ received more light $(95 \%)$ at 50 DAE which was followed by one hand weeding (90\%) and no weeding (88\%) treatments. Same trend was observed in soybean and blackgram intercropping combinations. Percent PAR interception was lower in earlier growth stages but it increased gradually up to 50 DAE in mungbean and blackgram in maize + blackgram association with the increase of foliage coverage of maize and legumes. Significantly the higher mean of PAR interception was recorded in intercrop treatments and sole cropped legume than that of sole cropmaize (Eskandari, 2012). Among the legume crops, the intensity and the quality of solar radiation intercepted by the canopy are important determinants of yield components and therefore yield of soybean since it is sensitive to shading (Liu et al., 2010). 

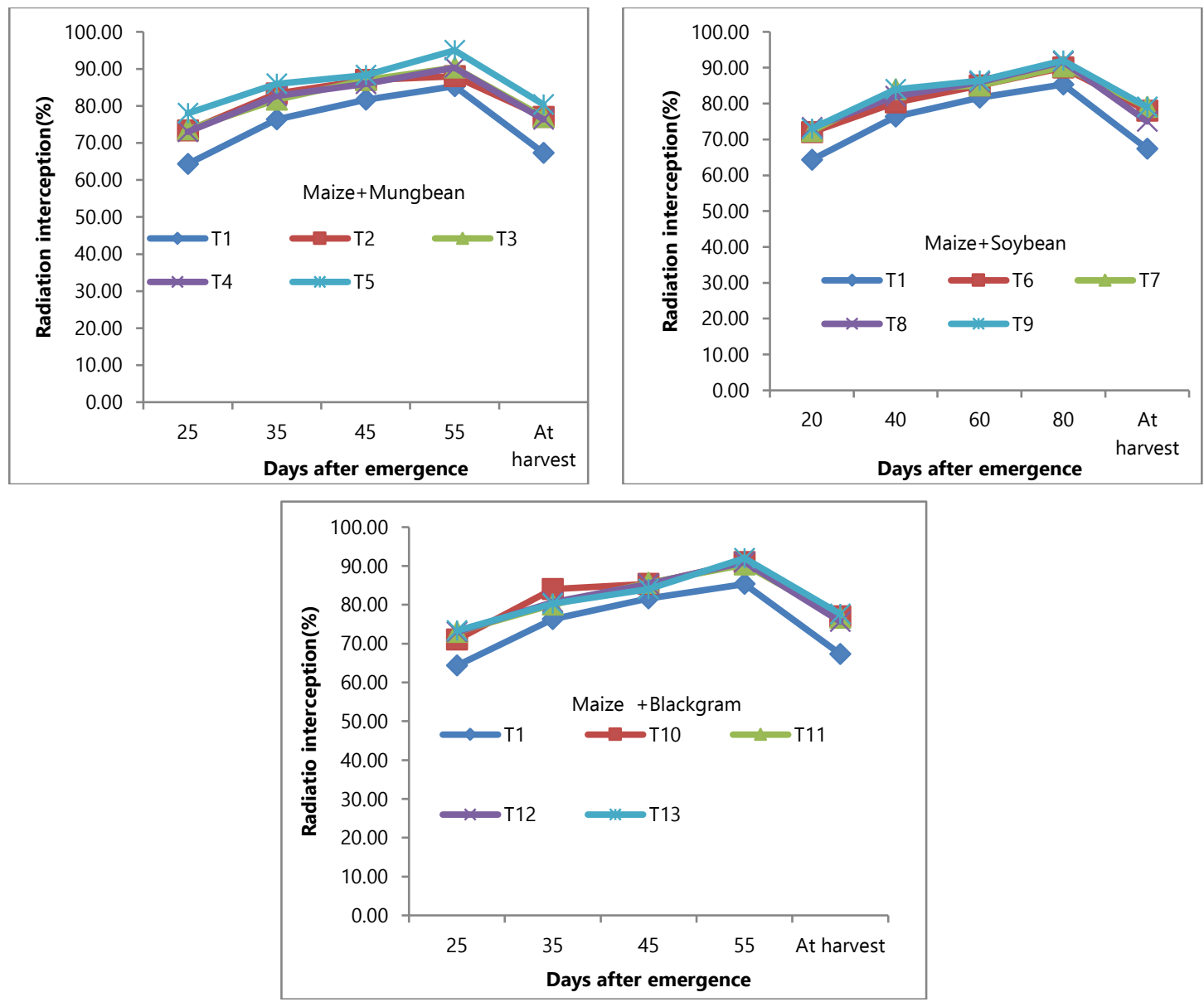

Fig.1. Photosynthetically active radiation interception of maize + legumes intercropping systems during the Kharif season of 2012.

Light levels during the late flowering to mid pod formation stages of growth have been found to be more critical than during vegetative and late reproductive periods (Liu et al., 2010). Differences in varietal arrangement of foliage and canopy architecture of intercrop components may lead to more PAR interception by intercropping compared with sole crops (Keating and Carberry, 1993).

\section{Total dry matter}

Total dry matter (TDM) production of maizewas significantly influenced by different legume intercropping systems and weeding regimes (Fig. 2). Dry matter accumulation of maize increased slowly and attained plateau at around $80 \mathrm{DAE}$ and then the pattern of curves remained similar until harvest. The highest dry matter accumulation of maize $\left(2065 \mathrm{~g} \mathrm{~m}^{-2}\right)$ was obtained in monoculture. It might be due to utilized solar radiation and $\mathrm{CO}_{2}$ as the plants were spaced planted with better nitrogen uptake and less weed infestation. Similar results were reported by Talukder et al. (2003).Among the intercropping systems in maize + mungbean with two hand weeding at 20 and $40 \mathrm{DAE}\left(\mathrm{T}_{5}\right)$ gave higher TDM than maize + soybean and maize + blackgram association at all the growth stages. The lowest dry matter accumulation was recorded in no weeding in all intercropped situation. 

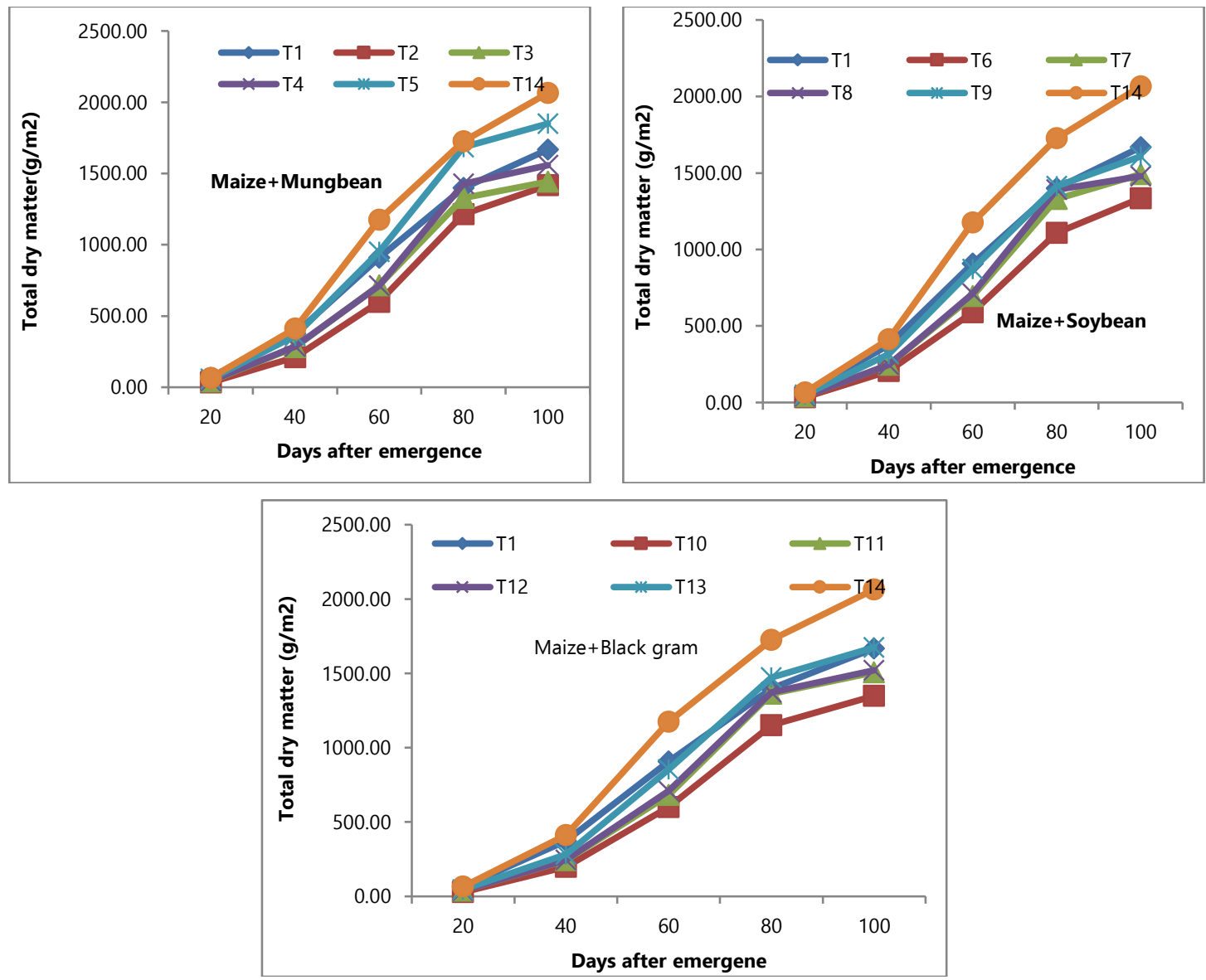

Fig. 2. Total dry matter of maize under various maize + legumes intercropping systems at different days after emergence during the Kharif season of 2012.

Intercrop legumes with lower density faced different levels of shading from different planting geometry of maize and subsequently accumulated lower dry matter (Kephart et al., 1992). The highest dry matter accumulation was observed in sole legumes than intercropped. Among all the intercropping systems mungbean gave higher dry matter accumulation than soybean and blackgram at all the growth stages.

\section{Leaf area index}

Leaf area index (LAI) ofmaize was significantly influenced by different legumes intercropping systems and weeding regimes at different days after emergence (Fig. 3). It was measured at 25, 35, 45, 55 DAE and at harvest of mungbean, blackgram and at 20,40,60,80 DAE and at harvest of soybean. LAI of maize reached to maximum at $80 \mathrm{DAE}$ and then decreased due to leaf senescence. Sole maize $\left(\mathrm{T}_{1}\right)$ produced significantly higher(3.74) LAI as compared to all intercropping treatments. 

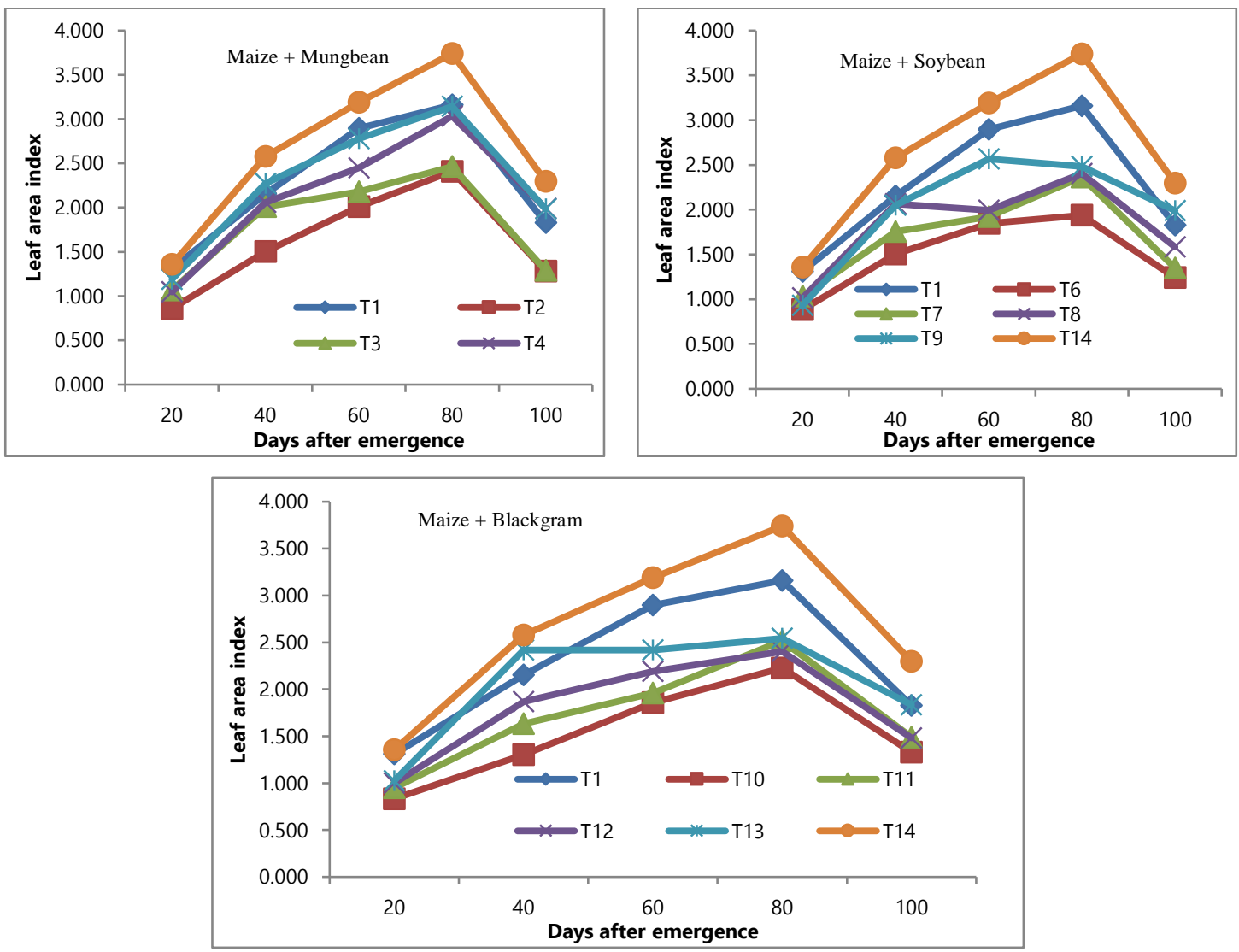

$\mathrm{T}_{1}=$ Sole maize (no weeding), $\mathrm{T}_{2}=$ Maize + Mungbean (no weeding), $\mathrm{T}_{3}=$ Maize + Mungbean (weeding at $20 \mathrm{DAE}$ ), $\mathrm{T}_{4}=$ Maize + Mungbean (weeding at $40 \mathrm{DAE}$ ), $\mathrm{T}_{5}=$ Maize + Mungbean (weeding at 20 and $\left.40 \mathrm{DAE}\right), \mathrm{T}_{6}=$ Maize + Soybean (no weeding), $\mathrm{T}_{7}=$ Maize + Soybean (weeding at $20 \mathrm{DAE}$ ), $\mathrm{T}_{8}=$ Maize + Soybean (weeding at $40 \mathrm{DAE}$ ), $\mathrm{T}_{9}=$ Maize + Soybean (weeding at 20 and $40 \mathrm{DAE}$ ), $\mathrm{T}_{10}=$ Maize + Blackgram (no weeding), $\mathrm{T}_{11}=$ Maize + Blackgram ( weeding at 20 DAE), $T_{12}=$ Maize + Blackgram (weeding at $40 \mathrm{DAE}$ ), $\mathrm{T}_{13}=$ Maize + Blackgram (weeding at 20 and $\left.40 \mathrm{DAE}\right), \mathrm{T}_{14}=$ Sole maize (weed free)

Fig. 3. Leaf area index of maize under various maize + legumes intercropping systems at different days after emergence during the Kharif season of 2012.

Similar results had been reported by Oljacaet al. (2000) who reported that sole maize produced higher LAI values than any other mixtures. LAI of maize was higher when it was intercropped with mungbean with two hand weeding $\left(\mathrm{T}_{5}\right)$ in all the growth stages. It ranged from 1.19 to 3.14 which was followed by maize + soybean ( 0.93 to 2.56 ) and maize + blackgram (1.02 to 2.54$)$ intercropping systems. Leaf area index was lowest in no weeding intercropping treatment at 20 DAE in maize under mungbean, soybean and blackgram combination which were statistically similar than that of other growth stages (Fig. 3). Thobatsi (2009) also found maize intercropped with cowpea long duration cultivar had significantly higher LAI.

\section{Yield and yield attributes of maize}

Yield and yield contributing characters were influenced significantly by different intercropping systems and weeding regimes (Table 2). Maximum cob length of maize was found in sole maize $(16.8 \mathrm{~cm})$ and maize + mungbean intercropping $\mathrm{T}_{5}(16.7 \mathrm{~cm})$. The lowest cob length was obtained from no weeding maize + soybean $(15.07 \mathrm{~cm})$ which was as par with $\mathrm{T}_{6}(15.13 \mathrm{~cm})$, treatment. Higher number of grains $\mathrm{cob}^{-1}$ was recorded from weed free sole maize (554) while lower number in no weeding maize + 
soybean (432) and maize + blackgram (436) intercropping system. Among the intercropping systems, maize + mungbean with two hand weedings gave higher grains $\operatorname{cob}^{-1}(501)$ than maize + blackgram and maize + soybean intercropping systems. Significant influence was observed in 1000-grain weight by the treatments. The maximum 1000-grain weight was recorded from maize + mungbean with two hand weedings intercropping system $(277.5 \mathrm{~g})$ which was statistically at par with weed free sole maize (276.9 $\mathrm{g})$, no weeding sole maize $(273.7 \mathrm{~g})$, one hand weeding at 20 DAE maize + mungbean intercropping plot $(272.4 \mathrm{~g})$ and maize + blackgram two hand weedings $(272 \mathrm{~g})$ treatments. Among the intercropping systems, maize + mungbean obtained higher grains weight than maize + blackgram and maize + soybean association. The highest grain yield was obtained from weed free sole maize $\left(8.05 \mathrm{t} \mathrm{ha}^{-1}\right)$ than unneeded sole maize $\left(6.48 \mathrm{t} \mathrm{ha}^{-1}\right)$ treatment (Fig. 4).

Table 2. Yield attributes of maize in maize + legumes intercropping system during the Kharif season of 2012

\begin{tabular}{lccc}
\hline Treatments & Cob length (cm) & Grains cob $^{\mathbf{1}}(\mathbf{n o .})$ & 1000-grain wt. $(\mathbf{g})$ \\
\hline $\mathrm{T}_{1}$ & $16.80 \mathrm{ab}$ & $486.3 \mathrm{~b}$ & $273.7 \mathrm{ab}$ \\
$\mathrm{T}_{2}$ & $15.53 \mathrm{bcd}$ & $459.0 \mathrm{bcde}$ & $260.5 \mathrm{f}$ \\
$\mathrm{T}_{3}$ & $15.48 \mathrm{~cd}$ & $473.0 \mathrm{bcde}$ & $272.4 \mathrm{abc}$ \\
$\mathrm{T}_{4}$ & $15.95 \mathrm{bcd}$ & $484.0 \mathrm{bc}$ & $268.3 \mathrm{bcde}$ \\
$\mathrm{T}_{5}$ & $16.67 \mathrm{abc}$ & $501.0 \mathrm{~b}$ & $277.5 \mathrm{a}$ \\
$\mathrm{T}_{6}$ & $15.13 \mathrm{~d}$ & $432.0 \mathrm{e}$ & $263.2 \mathrm{ef}$ \\
$\mathrm{T}_{7}$ & $15.73 \mathrm{bcd}$ & $440.7 \mathrm{cde}$ & $269.7 \mathrm{bcd}$ \\
$\mathrm{T}_{8}$ & $15.97 \mathrm{bcd}$ & $473.0 \mathrm{bcde}$ & $267.9 \mathrm{bcde}$ \\
$\mathrm{T}_{9}$ & $15.83 \mathrm{bcd}$ & $474.7 \mathrm{bcde}$ & $267.1 \mathrm{cde}$ \\
$\mathrm{T}_{10}$ & $15.07 \mathrm{~d}$ & $436.0 \mathrm{de}$ & $264.4 \mathrm{def}$ \\
$\mathrm{T}_{11}$ & $15.50 \mathrm{~cd}$ & $440.0 \mathrm{cde}$ & $265.8 \mathrm{def}$ \\
$\mathrm{T}_{12}$ & $15.92 \mathrm{bcd}$ & $471.7 \mathrm{bcde}$ & $269.1 \mathrm{bcde}$ \\
$\mathrm{T}_{13}$ & $15.90 \mathrm{bcd}$ & $478.7 \mathrm{bcd}$ & $272.0 \mathrm{abc}$ \\
$\mathrm{T}_{14}$ & $17.70 \mathrm{a}$ & $554.0 \mathrm{a}$ & $276.9 \mathrm{a}$ \\
\hline $\mathrm{CV}(\%)$ & 4.10 & 4.88 & 5.45 \\
\hline
\end{tabular}

The lowest yield was foundin unweeded maize plot in all intercropped situation. Among the intercropping situation, maize + mungbean with two hand weedings treatment marked higher grain yield $\left(7.18 \mathrm{t} \mathrm{ha}^{-1}\right)$ than maize + blackgram $\left(6.55 \mathrm{t} \mathrm{ha}^{-1}\right)$ and maize + soybean $\left(6.25 \mathrm{t} \mathrm{ha}^{-1}\right)$ intercropping systems. Higher yield of maize observed in monoculture compared to their respective intercropped might be due to no intercrop competition for light, nutrients, moisture and space. This corroborates with the findings of Uddin et al. (2003)who reported that maize yield was found to be highest from sole crop when intercropped with legume. The reduction of maize yield was probably due to intercrop competition between crops and weeds. Lower crop-weed competition under two hand weedings might have led to better yield components and thus resulted in higher yield (Mundra et al., 2003). 


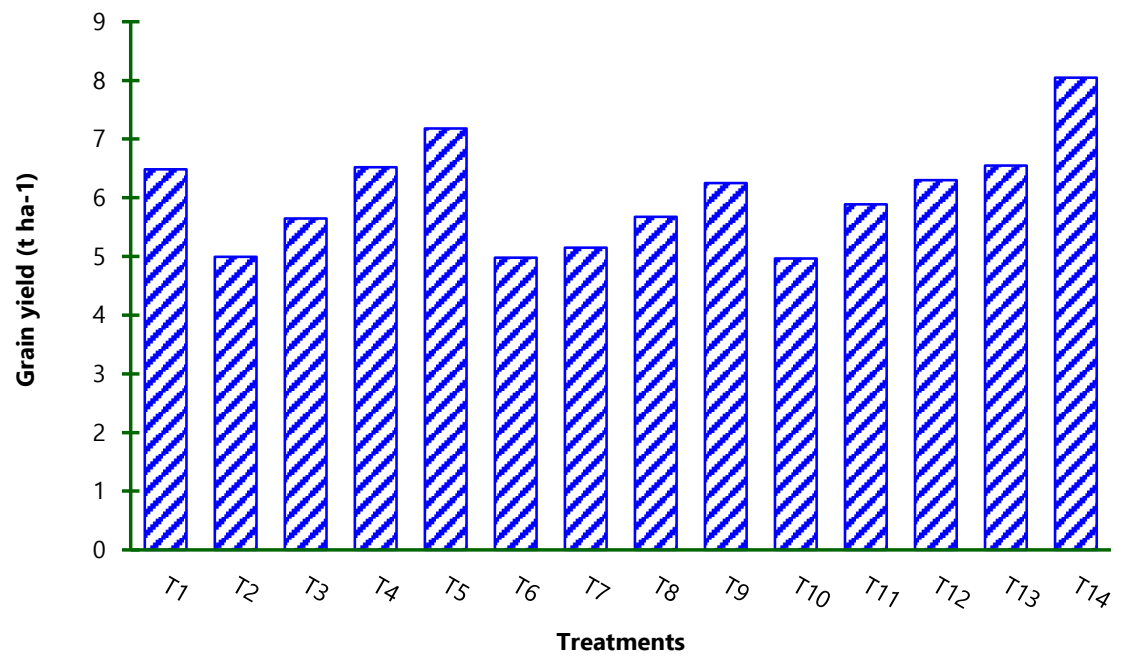

Fig. 4. Grain yield of maize in maize + legumesintercropping system in Kharif season.

\section{Yield and yield attributes of legumes}

All the yield characters of legumes were significantly influenced by the treatments of maize + legumes intercropping systems and the results are presented in Table 3. Higher number of pods plant ${ }^{-1}$ was recorded in intercropped soybean (80) which was statistically identical with sole soybean (78) and the lowest one was in intercropped mungbean (16.4) that was similar with others mungbean treatments. Among the legumes intercropping systems, maize + soybean was found in higher number of pods /plantwith varying weeding regime. Akhteruzzaman and Quayyum (1991)also reported that number of pods plant ${ }^{-1}$ of legumes were reduced by intercropping in Kharif season. The highest seeds pod ${ }^{-1}$ was obtained in sole legumes, except mungbean. Among the intercropping systems maize + mungbean intercropping in mungbean gave higher number of seeds pod ${ }^{-1}$ than other maize + soybean and maize + blackgram intercropping (Table 4). Maximum 1000-seed weight was observed in soybean mono cropping systems which was followed by soybean two hand weedings in intercropping treatments. The lowest 1000-seed weight was observed in blackgram intercropping treatments. Seed yield of legumes were influenced by the treatments in Kharif season (Fig. 5). Sole legumes produced the highest seed yield then it reduced significantly when it was grown in association with maize as intercrop. The higher seed yield produced from maize + mungbean intercropping with two hand weedings $\left(572.6 \mathrm{~kg} \mathrm{ha}^{-1}\right)$ which was followed by maize + blackgram $\left(510.8 \mathrm{~kg} \mathrm{ha}^{-1}\right)$ and maize + soybean $\left(502.9 \mathrm{~kg} \mathrm{ha}^{-1}\right)$ intercropping systems. The lowest yield was obtained by mungbean no weeding treatment $\left(302.4 \mathrm{~kg} \mathrm{ha}^{-}\right.$ 1) which was statistically similar with maize + blackgram no weeding $(316.6 \mathrm{~kg} / \mathrm{ha})$ and maize + soybean no weeding ( $\left.333.7 \mathrm{~kg} \mathrm{ha}^{-1}\right)$ treatments. Besides, legumes yield was poor due to less availability of light and nutrient in intercropping situation and also shading effect of maize. These findings are in accordance to those of Torofderet al. (2006). It also might be due two hand weedings intercropping systems favoured of intercropped mungbean and judicious use of growth resources compared to other intercropped combinations.

Table 3. Yield attributes of legumes in maize + legumes intercropping system during the Kharif season of 2012

\begin{tabular}{lccc}
\hline Treatments & $\begin{array}{c}\text { Pods plant }^{-1} \\
(\text { no. })\end{array}$ & $\begin{array}{c}\text { Seeds pod }^{-1} \\
(\text { no. })\end{array}$ & 1000-seed weight (g) \\
\hline $\mathrm{T}_{2}$ & $16.57 \mathrm{f}$ & $12.17 \mathrm{a}$ & $36.30 \mathrm{de}$
\end{tabular}




\begin{tabular}{lccc}
$\mathrm{T}_{3}$ & $16.43 \mathrm{f}$ & $13.33 \mathrm{a}$ & $37.13 \mathrm{cde}$ \\
$\mathrm{T}_{4}$ & $16.77 \mathrm{f}$ & $13.13 \mathrm{a}$ & $38.40 \mathrm{cde}$ \\
$\mathrm{T}_{5}$ & $18.83 \mathrm{f}$ & $13.53 \mathrm{a}$ & $39.63 \mathrm{bcde}$ \\
$\mathrm{T}_{6}$ & $52.67 \mathrm{c}$ & $2.467 \mathrm{c}$ & $31.33 \mathrm{f}$ \\
$\mathrm{T}_{7}$ & $70.67 \mathrm{~b}$ & $2.433 \mathrm{c}$ & $41.00 \mathrm{bc}$ \\
$\mathrm{T}_{8}$ & $70.33 \mathrm{~b}$ & $2.467 \mathrm{c}$ & $37.33 \mathrm{cde}$ \\
$\mathrm{T}_{9}$ & $79.67 \mathrm{a}$ & $2.500 \mathrm{c}$ & $43.33 \mathrm{ab}$ \\
$\mathrm{T}_{10}$ & $26.00 \mathrm{e}$ & $5.667 \mathrm{~b}$ & $35.17 \mathrm{ef}$ \\
$\mathrm{T}_{11}$ & $37.67 \mathrm{~d}$ & $5.667 \mathrm{~b}$ & $35.27 \mathrm{ef}$ \\
$\mathrm{T}_{12}$ & $35.43 \mathrm{~d}$ & $6.000 \mathrm{~b}$ & $36.07 \mathrm{de}$ \\
$\mathrm{T}_{13}$ & $38.57 \mathrm{~d}$ & $6.333 \mathrm{~b}$ & $36.63 \mathrm{cde}$ \\
$\mathrm{T}_{15}$ & $18.83 \mathrm{f}$ & $12.33 \mathrm{a}$ & $40.57 \mathrm{bcd}$ \\
$\mathrm{T}_{16}$ & $78.33 \mathrm{a}$ & $2.933 \mathrm{c}$ & $46.00 \mathrm{a}$ \\
$\mathrm{T}_{17}$ & $47.67 \mathrm{c}$ & $6.667 \mathrm{~b}$ & $39.27 \mathrm{bcde}$ \\
\hline $\mathrm{CV}(\%)$ & 8.97 & 10.47 & 6.16 \\
\hline
\end{tabular}

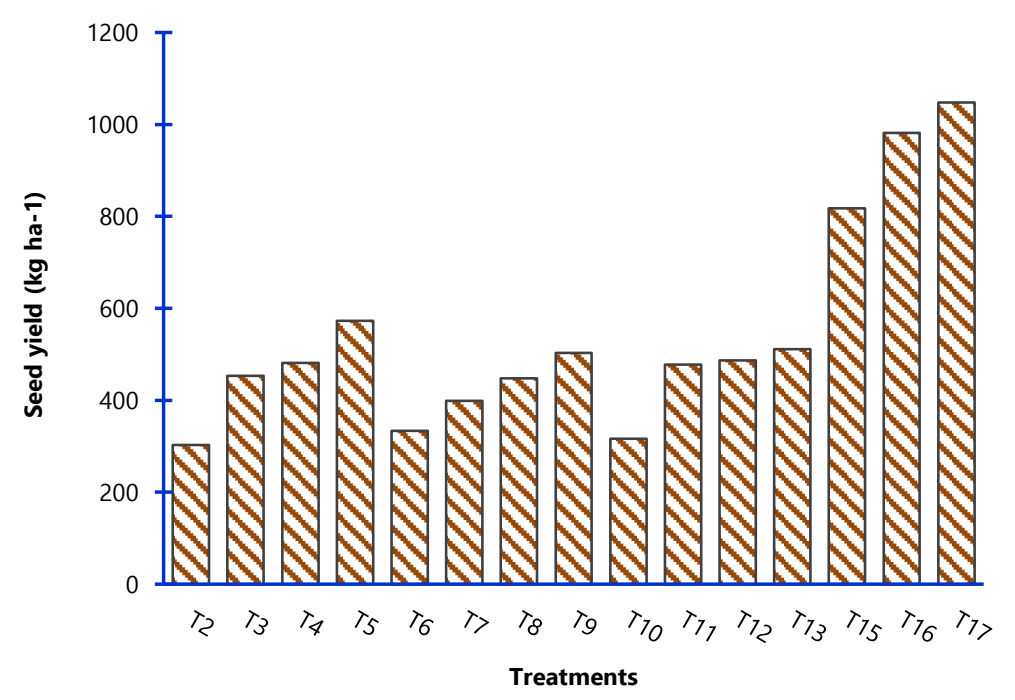

Fig. 5. Seed yield of legumes in maize legumes intercropping system in Kharif season.

\section{Evaluation of intercrop productivity}

Intercrop productivity was evaluated by equivalent yield and monetary advantage (Table4). The maximum maize equivalent yield $\left(12.49 \mathrm{tha}^{-1}\right)$ was obtained from $\mathrm{T}_{5}$ treatmentin both intercrop and sole situation. The lowest maize equivalent yield $\left(6.48 \mathrm{tha}^{-1}\right)$ was obtained from no weeding regime of sole maize.Patraet al. (2000)also reported similar observations in different intercropping systems. The results showed that the total gross return was higher in all the intercropping systems compared to their respective sole crop. The highest total gross return of Tk. $124900 \mathrm{ha}^{-1}$ was obtained from maize + mungbean intercropping with two hand weedings situation. On the other hand, the lowest gross return of Tk. 50643 ha $^{-1}$ was found from sole situation in mungbean treatment. The cost of cultivation increased in the intercropping systems compared with the respective sole crop of maize and legumes. It might be due to increased seed requirement and additional cultural practices for legumes in the intercropping systems. Similar results were also reported by Patel and Rajagopal (2001) under cereal + legume intercropping system. The highest cost of cultivation was observed in maize + soybean (Tk. $45035 \mathrm{ha}^{-1}$ ) intercropping systems. The lowest cost of cultivation was Tk. $30515 \mathrm{ha}^{-1}$ from sole 
mungbean. The cost of cultivation increased in the intercropping system over the respective sole crops of legumes due to addition of another crop in this system. The highest BCR (benefit cost ratio) was observed from same treatment of the maize + mungbean with two hand weedings situation (2.84). Sole maize with no weeding treatment gave lower BCR than other intercropping systems (1.60).

Table 4. Equivalent yield andeconomic analysis of maize + legume intercropping systems at different weeding regimes during the Kharif season of 2012

\begin{tabular}{|c|c|c|c|c|}
\hline Treatments & $\begin{array}{l}\text { Maize equivalent yield } \\
\left(t \text { ha }^{-1}\right)\end{array}$ & $\begin{array}{l}\text { Gross return } \\
(\text { Tk. ha } \\
\text { (1) }\end{array}$ & $\begin{array}{l}\text { Cost of cultivation } \\
\left(\mathrm{Tk} . \mathrm{ha}^{-1}\right)\end{array}$ & $\overline{\text { BCR }}$ \\
\hline $\mathrm{T}_{1}$ & 6.48 & 64800 & 40515 & 1.60 \\
\hline $\mathrm{T}_{2}$ & 7.93 & 79300 & 41715 & 1.90 \\
\hline $\mathrm{T}_{3}$ & 9.77 & 97700 & 43215 & 2.26 \\
\hline $\mathrm{T}_{4}$ & 9.98 & 99800 & 43215 & 2.31 \\
\hline $\mathrm{T}_{5}$ & 12.49 & 124900 & 44000 & 2.84 \\
\hline $\mathrm{T}_{6}$ & 8.14 & 81400 & 41034 & 1.98 \\
\hline $\mathrm{T}_{7}$ & 8.80 & 88000 & 42535 & 2.07 \\
\hline $\mathrm{T}_{8}$ & 9.76 & 97600 & 42535 & 2.29 \\
\hline $\mathrm{T}_{9}$ & 10.81 & 108100 & 45035 & 2.40 \\
\hline $\mathrm{T}_{10}$ & 8.00 & 80000 & 41115 & 1.95 \\
\hline $\mathrm{T}_{11}$ & 10.21 & 102100 & 42615 & 2.40 \\
\hline $\mathrm{T}_{12}$ & 10.76 & 107600 & 42615 & 2.52 \\
\hline $\mathrm{T}_{13}$ & 10.22 & 102200 & 43015 & 2.38 \\
\hline $\mathrm{T}_{14}$ & 8.05 & 82308 & 44675 & 1.84 \\
\hline $\mathrm{T}_{15}$ & 0.818 & 50643 & 30515 & 1.66 \\
\hline $\mathrm{T}_{16}$ & 0.982 & 65669 & 32785 & 2.00 \\
\hline $\mathrm{T}_{17}$ & 1.05 & 64322 & 30555 & 2.11 \\
\hline
\end{tabular}

$\mathrm{T}_{1}=$ Sole maize (no weeding), $\mathrm{T}_{2}=$ Maize + Mungbean (no weeding), $\mathrm{T}_{3}=$ Maize + Mungbean (weeding at $\left.20 \mathrm{DAE}\right), \mathrm{T}_{4}=$ Maize + Mungbean (weeding at $40 \mathrm{DAE}), \mathrm{T}_{5}=$ Maize + Mungbean (weeding at 20 and $\left.40 \mathrm{DAE}\right), \mathrm{T}_{6}=\mathrm{Maize}+\mathrm{Soybean}$ (no weeding), $\mathrm{T}_{7}=$ Maize + Soybean (weeding at $\left.20 \mathrm{DAE}\right), \mathrm{T}_{8}=$ Maize + Soybean (weeding at $\left.40 \mathrm{DAE}\right), \mathrm{T}_{9}=\mathrm{Maize}+$ Soybean (weeding at 20 and 40 DAE), $\mathrm{T}_{10}=$ Maize + Blackgram (no weeding), $\mathrm{T}_{11}=$ Maize + Blackgram ( weeding at 20 $\mathrm{DAE}$ ), $\mathrm{T}_{12}=$ Maize + Blackgram ( weeding at $\left.40 \mathrm{DAE}\right), \mathrm{T}_{13}=$ Maize + Blackgram (weeding at 20 and 40 DAE), $\mathrm{T}_{14}=\mathrm{Sole}$ maize (weed free), $\mathrm{T}_{15}=$ Sole Mungbean (weed free), $\mathrm{T}_{16}=$ Sole Soybean (weed free) and $\mathrm{T}_{17}=$ Sole Blackgram (weed free)

\section{Conclusion}

The results revealed that intercropping of two rows of mungbean in between two rows of maize with two hand weeding at 20 and 40 DAE appeared as a profitable practice for good yield advantages, optimum use of PAR, weed control efficiencies, and monetary values.

\section{References}

Ahmed, F., M.N. Islam, M.T. Rahman, M.A. Jahan and M.S.A. Khan. 2010. Leaf area index, radiation interception, dry matter production and grain yield of hybrid maize as influenced by plant spacing. Bangladesh Agron. J.13 (1 \& 2):51-58.

Akhteruzzaman, M. and M.A.Quayyum.1991. Intercropping of maize with three varieties of groundnut at two levels of plant population. Bangladesh J. Agril. Sci.18(1): 39-44.

Alom, M.S., N.K. Paul and M.A. Quayyum. 2010. Production potential of different varieties of hybrid maize (Zea mays L.) with groundnut (Arachishypogaea L.) under intercropping system. Bangladesh J. Agril. Res. 35(1): 51-64. 
Bandyopadhyay, S.N. 1984. Nitrogen and water relations in grain sorghum-legume intercropping systems. $\mathrm{Ph}$. D. Dissertation, Indian Agricultural Research Institute, New Delhi.

Banik, P., A.Midya, B.K.Sarkar and S.S. Ghose. 2006. Wheat and chickpea intercropping systems in an additive experiment. Advantages and weed smothering. European J.Agron.24:325-328.

BBS. 2017. Yearbook of Agricultural Statistics of Bangladesh-2018.Bangladesh Bureau of Statistics. Ministry of Planning. Govt. of the Peoples' Republic of Bangladesh. pp.73-110.

Baumann, D.T., M.J. Kropf and L. Bastiaans. 2000. Intercropping leeks to suppress weeds. Weed Res. 40: 361-376.

Cruz, F.D., K.Moody and M.B.D. Ramas. 1986. Reducing variability sampling weeds in upland rice(Oryza sativa). Philopp J. Weed Sci.13: 56-59.

Dogan, M.N., A. Unay, O. Boz and F. Albay. 2004. Determination of optimum weed control timing in maize (Zeamays L.). Turkish J. Agron., 28: 349-354.

Dwivedi, S.K. and G.K. Shrivastava. 2011. Planting geometry and weed management for maize (Zea mays) - blackgram (Vignamungo) intercropping system under rainfedvertisols. Indian J. Agron.56(3): 202-208.

Eskandari, H. 2012. Intercropping of maize (Zea mays) with cowpea (Vignasinensis) and mungbean (Vignaradiata): Effect of complementarity of intercrop components on resource consumption, dry matter production and legumes forage quality. J. Basic. Appl. Sci. Res. 2(1): 355-360.

Gao, Y., A. Duan, X. Qiu, J. Sun, J. Zhang, H. Liu and H. Wang. 2010. Distribution and use efficiency of photosynthetically active radiation in strip intercropping of maize and soybean. Agron.J. 102(4): 1149-1157.

Gharineh, M.H. and S.A.Moosavi. 2010. Effects of intercropping (canola-fababean) on density and diversity of weeds. Notulae Sci. Biol. 2(4):109-112.

Kadziuliene, Z., L. Sarunaite, I. Dereikyte, S. Maiksteniene, A. Arlauskiene, L. Masilionyte, R. Cenuleviciene and V. Zekaite. 2009. Qualitative effects of pea and spring cereals intercrop in the organic farming systems. Agron. Res.7(2):606-611.

Katsaruware, R.D. and I.O. Manyanhaire. 2009. Maize-cowpea intercropping and weed suppression in leaf stripped and detasselled maize in Zimbabwe. J. Environ. Agric Food Chem. 8(1): 1218-1226.

Keating, B.A. and P.S. Carberry. 1993. Resource capture and use in intercropping: solar radiation.Field Crops Res.34: 273-301.

Kephart, K.D., D.R. Buxton and S.E. Taylor. 1992. Growth of $\mathrm{C}_{3}$ and $\mathrm{C}_{4}$ perennial grasses in reduced irradiance. Crop Sci.32: 1033-1038.

Li, L.S., J. Zhang, X.F. Li, S.Yang and Z. Rengel.2001. Wheat/maize or wheat/ soybean strip intercropping yield advantage and interspecific interaction on nutrients. Field Crops Res. 71: 123-137.

Liu, B., X.B. Liu, C.Wang,J. Jin, S.J. Harbert and M. Hashemi. 2010. Response of soybean yield and yield components to light enrichment and planting density. Int. J. Plant Prod.4(1): 1-10.

Mundra, S.L., A.K.Vyas and P.L.Maliwal. 2003. Effect of weedand nutrient management on weedgrowth and productivityof maize(Zea mays L.). Indian J. Weed Sci. 35(1\&2):57-61.

Muoneke, C.O., M.A.O.Ogwuche and B.A. Kalu. 2007. Effect of maize planting density on the performance of maize/soybean intercropping system in a Guinea Savannah Agro-ecosystem. African J. Agril. Res.2(12):667-677.

Oijaca, S., R. Cvetkovic, D. Kovacevic, G. Vsiii and N. Momirovic. 2000. Effect of plant arrangement pattern and irrigation on efficiency of maize and bean intercropping system. J. Agric. Sci.135: 261270.

Pandey, A.K. andV.Prakash. 2002. Weed management in maize and soybean intercropping system.Indian J.Weed Sci.34(1\&2): 58-62.

Patel, J.R. and S. Rajagopal. 2001. Production potential of forage maize (Zea mays L.) with legumes under intercropping systems. Indian J. Agron.46(2):211-215. 
Patra, B.C., B.K. Mandal and A.L. Padhi. 2000. Production potential of winter maize (Zea mays L.) based intercropping systems. Indian J. Agril. Sci.70(4):203-206.

Poggio, S.L. 2005. Structure of weed communities occurring in monoculture and intercropping of field pea and barley. J. Agric. Ecosys. Environ. 109:48-58.

Quayyum, M.A. and A.F.M. Maniruzzaman. 1995. Effect of maize (Zea mays L.) and rice (Oryza sativa) with blackgram (Phaseolusmungo). Indian J. Agron. 40(1): 20-25.

S. Maitra, D.C. Ghosh, G.Sounda, P.K. Jana and D.K. Roy.2000.Productivity, competition and economics of intercropping legumes in finger millet (Eleusinecoracana) at different fertility levels.Indian J. Agric. Sci.70(12):824-828.

Talukder, A.S.M.H.M., M.A. Sufian, C.A. Meisner, J.M. Duxbury, J.G. Lauren and A.B.S. Hossain. 2003. Rice, wheat and mungbean yields in response to $\mathrm{N}$ levels and management under a bed planting systems. Bangladesh J. Ghurpukur, Shatkhira.5:44-48.

Thobatsi, T. 2009. Growth and yield responses of maize (Zea mays L.) and cowpea (VignaunguiculataL.) in an intercropping system. MSc. Thesis. University of Pretoria. 159p.

Torofder, G.S., A.Ahmed,M.M. Alam and M.A. Quayyum. 1992. Intercropping of maize with different legume. Bangladesh J. Life Sci. 4(2): 33-37.

Trenbath, B.R. 1986. Resource use by intercrops. In: CA Francis (Ed), Multiple Cropping Systems. MacMillan Pub. Co.866 Third Avenue, New York 10022. pp.57-81.

Uddin, M.S., M.J.Rahman, S.A. Begum and M.R. Ali. 2003. Intercropping of maize with soybean in saline area under rainfed condition. Bangladesh J. Agril. Res. 28(3): 451-455. 